\title{
Kampanye Dan TeleVisi \\ (Analisis Pemberitaan Kampanye Pemilu Legislatif 2009 di TV Borobudur)
}

\author{
Edi Nurwahyu Julianto \\ (edi_tvb@yahoo.co.id) \\ Pengajar Jurusan Ilmu Komunikasi Universitas Semarang
}

\begin{abstract}
:
In the context of the current information age, media power is great considered in the flow of information spread quickly and widely. The political elite use media to socialize the political agenda. Institutions of mass media like television and newspapers is believed to have ability in organizing the production, reproduction and distribution of knowledge significantly. A series of symbols that gives meaning of the reality of "there" and experience in life, can be transformed in the public sphere of mass media, which can be accessed by members of society. Public trust what was presented in the media. Media does have a significant force in the conduct of production and reproduction of political image and content of media as a reality that has been constructed (constructed reality).
\end{abstract}

Kata Kunci : Constructed Reality, Political Agenda, Media

\section{Pendahuluan}

Satu fenomena yang menonjol dalam Pemilu 2009 adalah semakin kuatnya peranan media massa di Indonesia dalam proses mengkonstruksi citra para kandidat baik perseorangan (caleg, capres dan cawapres) maupun organisasi partai politik. Pemanfaatan media untuk mendongkrak popularitas sebenarnya telah mulai marak dan bebas sejak Pemilu 1999 dan semakin menguat di Pemilu 2004 hingga Pemilu kali ini. Bisa kita katakan kemenangan SBY pada Pemilihan Presiden secara langsung pada Pemilu Presiden dan wakil Presiden 2004 merupakan keberhasilan marketing politik team suksesnya dalam memanfaatkan media. Pasalnya, sebagai peserta Pemilu, Partai Demokrat merupakan pendatang baru dalam hajatan pesta demokrasi 5 tahunan di Indonesia.

Pada Pemilu 2009, masa kampanye diperpanjang menjadi 9 bulan dimulai 12 Juli 2008 sampai April 2009. Dengan 38 partai peserta Pemilu tentunya kian meramaikan "pertarungan citra" dalarn merebut hati para pemilih. Kandidat yang menguasai industri citra tentunya akan memperbesar peluangnya memenangkan pertarungan tersebut. Peran media sebagai pembentuk citra tersebut tentu saja menjadi sangat berarti bagi para elite politik, terutama di era sekarang ini manakala hampir sebagian besar proses politik sebenarnya merupakan mediated politics atau bahkan media-driven politik, yaitu era dimana aktivitas politik cenderung dikendalikan oleh media.

Dalam konteks era informasi sekarang ini, kekuatan media dinilai begitu dahsyat dalam menyebar arus informasi secara cepat dan meluas. Para elite politik jelas lebih memanfaatkan media massa sebagai sarana untuk bersosialisasi agenda politik. Institusi media massa seperti televisi dan surat 
kabar dipercaya memiliki kemampuan dalam menyelenggarakan produksi, reproduksi dan distribusi pengetahuan secara signifikan. Serangkaian simbol yang memberikan makna tentang realitas "ada" dan pengalaman dalam kehidupan, bisa ditransformasikan media massa dalam lingkungan publik, sehingga bisa diakses anggota masyarakat secara luas. Publik secara otomatis akan terbius oleh manisnya informasi melalui media massa yang telah disetting. Media memang memiliki kekuatan yang signifikan dalam melakukan produksi dan reproduksi citra politik dan isi media sebagai realitas yang telah dikonstruksikan (constructed reality). Tak heran bila dalam pemilihan umum, media massa merasa diuntungkan secara finansial, mengingat jumlah penonton pun makin meningkat seiring untuk memenuhi kebutuhannya akan informasi tentang keberadaan elite politik yang bertarung dalam pemilu legislatif, diharapkan dengan informasi yang ada dalam media mampu menjadi referensi dalam menentukan pilihannya dalam pemungutan suara.

\section{Pembahasan}

Survei kepermisaan televisi yang dilakukan AGB Nielsen Media Research di 10 kota besar di Indonesia periode Januari-Juni 2009 memperlihatkan pemirsa televisi berita, yakni MetroTV dan TV One melonjak tajam saat memasuki tahapan Pemilu 2009. Menurut Associate Director Marketing Service and Client Service AGB Nielsen, Hellen Katherina, jumlah pemirsa berita di stasiun TV berita bertambah sejak pemilu legislatif pada April, dan sesudahnya jumlahnya bahkan melampaui perolehan pemirsa berita di stasiun TV non-berita, dirnana pemirsa berita Metro TV dan TVO ne bertambah
28 persen, menjadi rata-rata 23.000 orang di kuartal II April sampai Juni 2009. Dalam risetnya AGB Nielsen mencatat, selama Januari-Juni pasokan berita tertinggi di bulan April seiring pelaksanaan pemilu legislatif, yaitu mencapai rata-rata 45 jam sehari di antara 10 TV swasta nasional (www.depkominfo.go.id).

Namun dalam menyongsong pemilu legislatif, keuntungan juga dirasakan oleh media lokal, pasalnya dianggap lebih dekat dengan daerah pemilihannya (dapil). Dalam melakukan pendekatan terhadap publik, hampir semua calon memanfaatkan media lokal, baik cetak maupun elektronik. Bisa dimengerti, media mampu menjangkau khalayak sasaran yang lebih luas dibandingkan berbagai cara konvensional, seperti rapat umum, pemasangan spanduk, baliho, atau penempelan stiker. Kita menyaksikan berbagai sosialisasi calon legislatif dikemas tidak saja dalam bentuk iklan display, tetapi juga berita advertorial dan dialog interaktif yang melibatkan sejumlah stasiun radio dan televisi swasta. Momen pemilu legislatif menciptakan relasi saling menguntungkan antara media lokal dan para kandidat caleg ataupun parpol pengusungnya. Kebutuhan setiap calon akan sosialisasi diterjemahkan media sebagai peluang emas untuk meraup pemasukan guna meneguhkan atau bahkan mempertahankan eksistensi di tengah ketatnya persaingan bisnis media lokal.

Dalam konteks pemilu legislatif, publik berharap agar media lokal mampu secara kritis mengupas tuntas latar belakang setiap calon yang berlaga dalam pemilu legislatif dengan program yang ditawarkannya sehingga publik 
memiliki pengetahuan yang cukup akurat guna menjatuhkan pilihan dengan tepat di bilik suara nantinya. Tak hanya itu, publik pun berharap media menjadi fasilitator sosialisasi dari jajaran penyelenggara pemilu baik KPU ataupun Panwaslu terkait kebijakan-kebijakan dalam pemilu legislatif 2009 sehingga dalam pelaksanaan pemungutan suara, masyarakat tak mengalami kebingungan apa yang harus dilakukannya, dari pemberian penandaan surat suara, menggunakan hak pilihnya di luar TPS asal, hingga tahapan dan mekanisme pemilu itu sendiri. Asumsi yang mendasari ekspektasi publik sederhana saja; media lokal adalah media yang dianggap tahu atau semestinya paling paham seluk-beluk permasalahan lokal.

Sayangnya, alih-alih menjadi pengawal demokrasi pada tataran lokal, yang banyak terjadi adalah media lokal justru bermain mata dengan calon pemegang kekuasaan. Bukannya menurunkan laporan yang sesuai dengan kredo "bad news is good news" demi kepentingan umum, kita mengamati begitu banyak media lokal justru berlomba-lomba menampilkan yang terbaik dan terindah tentang elite politik yang menjadi kliennya. Serangkaian program yang digelar, mulai dari talk show hingga dialog interaktif, semuanya mempunyai ending yang sama: puja-puji untuk sang calon. Sepanjang seorang calon mampu menjalin "hubungan baik" dengan media, calon tersebut bisa menentukan apa yang ingin dimuat, bagaimana penberitaan (coverage) tentang dirinya selalu dikemas dan seterusnya.

Sebaiknya, media massa harus tunduk pada Kode Etik Jurnalistik dan Undang-Undang Pers No 40/1999 menghendaki agar melakukan pekerjaan profesinya secara jujur obyektif dan bertanggung jawab dengan menampilkan liputan yang berimbang dan menjauhkan diri dari perbuatan tercela seperti memfitnah atau melansir berita-berita yang sangat spekulatif dan merusak reputasi dan citra dari anggota masyarakat yang diliputnya. Tak hanya itu dalam pemberitaan pemilu legislatif, media massa harus tunduk pada UU Nomor 10 Tahun 2008 tentang "Pemilihan Umum Anggota Dewan Perwakilan Rakyat, Dewan Perwakilan Daerah, dan Dewan Perwakilan Rakyat Daerah".

Bagaimanapun juga setiap media massa memiliki karakter dan latar belakang tersendiri, baik dalam isi dan pengemasan beritanya, maupun dalam tampilan serta tujuan dasarnya. Perbedaan ini dilatarbelakangi oleh kepentingan yang berbeda dari masingmasing media massa. Baik yang bermotif politik, ekonomi, agama dan sebagainya. Seperti yang dikatakan oleh Bambang Harimurti bahwa media masa merupakan kumpulan banyak organisasi dan manusia dengan segala kepentingannya yang beragam, bahkan termasuk yang saling bertentangan. (Septiawan, $2005: 34$ ).

Persoalan media massa pada umumnya selain terkait dengan aspek budaya juga menyangkut kepentingan politik dan ekonomi. Konsep politik ekonomi merupakan derivasi dari bahasa Yunani, ekonomi (oikos dan nomos) terkait pada tata-atur rumah tangga, politik (polis) berdimensi kota-negara (city-state). Ini menjadi embrio bagi lahirnya konsepsi politik ekonomi klasik, ditandai oleh munculnya pandangan liberal yang diawali oleh Adam Smith, David Ricardo, dan kawan-kawan. Selanjutnya, politik 
ekonomi dipandang sebagai kombinasi dan kajian relasi negara/pemerintah terhadap aktivitas industri individu (Palgrave, 1917). Dengan demikian, konsepsi politik ekonomi dapat dirumuskan sebagai studi tentang relasirelasi sosial, khususnya relasi kekuasaan, yang dalam interaksinya secara bersamasama menentukan sisi produksi, distribusi dan konsumsi sumber daya (Vincent Mosco, 1996). Bila dikaitkan dengan wilayah komunikasi, khususnya industri media massa, sumber daya yang dimaksud berupa surat kabar, televisi, buku, video, film, pemirsa dan seterusnya. Produk-produk ini menjadi sumber daya (resource) untuk didistribusikan ke publik dan dikonsumsi. Rangkaian pola produksi, distribusi, dan konsumsi dalam industri media massa melibatkan relasi pihak jurnalis, organisasi media, pemilik modal atau kapitalis (perspektif ekonomi-bisnis), dan negara atau tepatnya pemerintah (perspektif politis) (http://jurnal.bl.ac.id/wpcontent/uploads/2007/11/veraseptember2 007).

Dari pengamatan penulis peranan TV Borobudur selama pelaksanaan kampanye terbuka lebih berpihak pada penyelenggara pemilu (KPU, Panwas hingga Jajaran Pemerintah) dibandingkan pemberitaan seputar aktivitas kampanye terbuka yang dilakukan oleh parpol ataupun caleg.

Pemberitaan seputar aktivitas kampanye terbuka, tidak ter-cover dengan baik, sehingga agenda kampanye yang dilakukan tokoh-tokoh nasional, seperti JK-Golkar, Prabowo-Gerindra dan Wiranto-Hanura tidak diliput. Kondisi serupa juga terjadi untuk calegcaleg lokal yang sama sekali tidak pernah muncul dalam pemberitaan.
Keberadaan caleg atau parpol muncul dalam pemberitaan TV Borobudur bila sedang tersangkut persoalan pelanggaran pemilu, protes terhadap kebijakan pemilu dan memberikan tanggapantanggapan persoalan pemilu di luar sosialisasi program-program kampanyenya. Persoalan tidak diliputnya berita kampanye terbuka ini lebih disebabkan regulasi pemilik modal yang membatasi pemberitaan tentang kampanye.

Dalam pandangan pemilik modal, media televisi berbeda dengan surat kabar, dimana untuk kelangsungan hidupnya bergantung pda pihak ketiga (iklan). Kondisi ini berbeda dengan surat kabar yang kelangsungan hidupnya selain ditentukan oleh iklan juga dari penjualan oplah surat kabarnya. Untuk itu media surat kabar seringkali memberitakan kampanye terbuka yang dinilai sangat dibutuhkan oleh pembacanya. Sementara di televisi, untuk menyaksikan acara-acara yang disajikan, masyarakat tidak dipungut biaya apapun. Kondisi inilah yang mempengaruhi kebijakan TV Borobudur dalam menyajikan berbagai acara, tcnnasuk berita. Parpol atau caleg yang tidak bersedia melakukan transaksi pemberitaan peliputan maka tidak boleh diliput.

Kondisi ini sebenarnya sangat bertentangan dengan jajaran redaksi yang lebih obyektif dalam menyikapi pemberitaan. Apapun selama memiliki news value dan bermanfaat bagi audience, peristiwa apapun dapat diberitakan. Hanya saja redaksi tidak memiliki kekuatan lebih untuk menyajikan berita-berita kampanye tanpa seizin pemilik modal. Oleh karenanya, caleg-caleg ataupun parpol yang muncul dalam pemberitaan TV 
Borobudur biasanya menyangkut persoalan pelanggaran yang dilakukan oleh parpol ataupun caleg bersangkutan. Seperti dugaan pelanggaran calon anggota DPD Jateng Sulistyo, pembubaran rapat Partai Demokrat di rumah dinas walikota.

Sementara itu, untuk dapat masuk dalam pemberitaan TV Borobudur dengan materi pemberitaan selama dua menit tak sedikit uang yang harus dikeluarkan oleh parpol ataupun caleg. Yakni dengan kisaran Rp.750.00 hingga Rp. $\quad 1.500 .000$ tergantung penempatan berita. Apakah di berita TVB, Khutane Dhewe dan TVB Pagi. Materi yang tidak sedikit jumlahnya ini tentu saja dinilai terlalu berat bagi calegcaleg lokal dengan keterbatasan modal untuk melakukan kampanye.

\section{Implikasi}

Implikasi dari kekuatan pemilik modal dalam mempengaruhi konten materi pemberitaan adalah reporter di lapangan tidak berani meliput berita tanpa seizin redaksi. Siasat yang dapat dilakukan untuk melibatkan para caleg dan parpol adalah menggabungkan statement mereka dengan para pengamat politik ataupun penyelenggara kampanye (KPU ataupun Panwaslu). Di jajaran redaksi, berita-berita kampanye yang memiliki kerawanan untuk ditayangkan harus dilaporkan ke pemilik modal, apakah dapat ditayangkan atau tidak. Cara lain yang dapat dilakukan adalah menempatkan berita-berita dalam kategori rawan ini di penayangan TVB Pagi dengan memberikan judul berita yang tidak menyebutkan nama parpol. Langkah ini diambil karena penayangan TVB Pagi jarang dimonitor oleh pemilik modal yang biasa hanya menerima dan mencermati laporan tertulis dari redaksi.

\section{Penutup}

Dari paparan analisis diatas dapat disimpulkan dua hal sebagai berikut:

1. Dalam mengkontruksi peristiwa kampanye terbuka pemilu legislatif 2009 yang berlangsung di Kota Semarang, TV Borobudur lebih berpihak pada penyelenggara pemilu (KPU, Panwas hingga jajaran pemerintah) dibandingkan pemberitaan seputar aktivitas kampanye terbuka yang dilakukan oleh parpol ataupun caleg. Kondisi ini terjadi karena kebijakan media berada sepenuhnya di tangan pemilik modal yang mensyaratkan faktor ekonomi demi kelangsungan bisnis. Partai politik atau caleg yang berani membayar maka akan mendapat porsi pemberitaan.

2. Dalam hajatan pemilu legislatif 2009 , masih banyak caleg yang tidak memanfaatkan media massa sebagai media untuk kampanye. Strategi kampanye door to door dinilai lebih efektif untuk menarik dukungan suara. Belum dimanfaatkannya media massa lebih dikarenakan akses terbatas dengan pelaku media dan biaya yang dibutuhkan cukup banyak.

\section{Daftar Pustaka}

Santana K, Septiawan. (2005). Jurnalisme Kontemporer. Jakarta. Yayasan Obor Indonesia. http://jurnal.bl.ac.id/wpcontent/uploads/2007/11 /veraseptember2007.pdf. www.depkominfo.go.id 